\title{
Dentition of Nansei Islanders and Peopling of the Japanese Archipelago: The Basic Populations in East Asia, IX
}

\author{
Tsunehiko HANIHARA \\ Department of Anatomy, Jichi Medical School
}

\begin{abstract}
The dental features of 4 geographical samples from the Nansei Island chain were compared with those of East and Southeast Asian samples. The series from Amami-, Okinawa-, and Sakishima-Islands exhibit inter-regional difference in both metric and non-metric dental features, pointing to some clinal variation in the Nansei Island chain. The original morphology is supposed to be represented by Jomonese. This clinal variation may reflect the post-Yayoi biocultural microevolution and admixture with the sinodont populations from main-island Japan. The sundadont ancestors of Jomonese have likely arrived from Sundaland via the now-submerged East Asian continental shelf in and after the late Pleistocene. One of the main routes for peopling of the Japanese Archipelago might have been through the Nansei Island chain.
\end{abstract}

Key Words Nansei Island chain, Jomonese, Sundadont, Sundaland, Peopling of the Japanese Archipelago

\section{Introduction}

A dual structure model for the population history of Japanese proposed by HANIHARA, K. (1991) explains the geographical variation of modern Japanese physical characteristics under a single hypothesis. Marked differences in the physical traits of the Neolithic Jomon people, or Jomonese, and those of some Aeneolithic Yayoi populations as represented by the skeletal remains excavated from Doigahama site in the westernmost part of Honshu and Kanenokuma and Mitsu-Nagata sites in the northern part of Kyushu, show that modern Japanese have separate primary origins. However, during the period from the Yayoi to early historic ages, or from 2,300 years B.P. to 1,300 years B.P., admixture between the aboriginal Jomonese and the incoming Yayoi people from Northeast Asia blurred the distinction of the two population systems. The impact of the migrants after the Yayoi age is unexpectedly large, so that a majority of modern Japanese carry a large amount of the Northeast Asian characteristics (HANIHARA, K., 1985, 1987, 1991; TURNER, 1987; DODO and ISHIDA, 1990). However, some geographically isolated Japanese, e.g. Ainu, the residents of Okinawa, Tokunoshima, etc., are clearly descended from Jomonese (HANIHARA, T., 1989a, b, c, 1990a, b, c, 1991a, b, c, n.d. a, b).

TURNER (1976, 1979, 1987, 1989, 1990) supposed that the sundadont ancestors of 
Jomonese could be traced back to the hypothetical populations of the late Pleistocene Sundaland. In a series of my previous studies, I have suggested that the physical characteristics of the 'generalized Asiatic populations', as represented by Negritos of Philippines, Dajaks of Borneo, and some Lesser Sunda Islanders, may have been similar to those of the hypothetical late Pleistocene Sundaland populations. Moreover, the generalized Asiatic populations may be linked with Jomonese (HANIHARA, T., 1991a, b, c).

Based on such findings, the next study should be focused on the geographical source, or routes for extension of the ancestral populations in the Japanese Archipelago. The dental and cranial affinities between the Palaeolithic Minatogawa man from Okinawa (ca. 17,000 years B.P.) and the Neolithic Jomonese provide an evidence that the latter migrated from the south into mainisland Japan through the Nansei Island chain (SUZUKI and HANIHARA, 1982; TURNER, 1987, 1990). In the present study, the major purposes are to describe the dental characters of Nansei Islanders and to provide an additional origin and route hypothesis for the peopling of the Japanese Archipelago.

\section{Materials and Methods}

The materials consist of prehistoric and near contemporary samples from the Japanese Archi-

Table 1. Materials used (N: male)

\begin{tabular}{|c|c|c|c|}
\hline Sample name & $\mathbf{N}$ & Preservation & Provenience \\
\hline Amami Islands & 122 & $\begin{array}{l}\text { Univ. Tokyo } \\
\text { Kyoto Univ. etc. } \\
\text { Kagoshima Univ. }\end{array}$ & $\begin{array}{l}\text { Amamioshima-, Kikai-, Yoro-, } \\
\text { Yoron-, Okinoerabu-, } \\
\text { Tokunoshima-island }\end{array}$ \\
\hline Okinawa Islands & 34 & $\begin{array}{l}\text { Univ. Tokyo } \\
\text { Kyoto Univ. }\end{array}$ & Okinawa island \\
\hline Sakishima Islands & 39 & $\begin{array}{l}\text { Univ. Tokyo } \\
\text { Kyoto Univ. etc. }\end{array}$ & $\begin{array}{l}\text { Miyako-, Ishigaki-, Hateruma-, } \\
\text { Yonaguni-island }\end{array}$ \\
\hline Hirota & 21 & Kyushu Univ. & $\begin{array}{l}\text { Hirota site, Tanegashima island } \\
(2,300-1,700 \text { years B.P. })\end{array}$ \\
\hline \multicolumn{4}{|c|}{ Comparative samples } \\
\hline Jomonese & 106 & $\begin{array}{l}\text { Univ. Tokyo } \\
\text { Nat. Sci. Museum }\end{array}$ & $\begin{array}{l}\text { Late and the latest Jomon period } \\
(3,500-2,300 \text { years B.P.) }\end{array}$ \\
\hline Honshu Japanese & 30 & $\begin{array}{l}\text { Univ. Tokyo } \\
\text { Jichi Med. Sch. }\end{array}$ & $\begin{array}{l}\text { Mainly from Kanto region including } \\
\text { western part of Honshu }\end{array}$ \\
\hline Kyushu Japanese & 58 & Kagoshima Univ. & $\begin{array}{l}\text { Bonotsu, South end of Kyushu, } \\
\text { Kagoshima Prefecture }\end{array}$ \\
\hline Kanenokuma & 27 & Kyushu Univ. & $\begin{array}{l}\text { Kanenokuma site, Fukuoka Pref., Kyushu } \\
(2,300-1,700 \text { years B.P.) }\end{array}$ \\
\hline Chinese & 87 & $\begin{array}{l}\text { Univ. Tokyo } \\
\text { Kyoto Univ. }\end{array}$ & $\begin{array}{l}\text { Near contemporary Manchurian } \\
\text { Liaoning and Kirin Pref. }\end{array}$ \\
\hline Korean & 26 & $\begin{array}{l}\text { Univ. Tokyo } \\
\text { Kyoto Univ. }\end{array}$ & Near contemporary Koreans \\
\hline Negrito & 21 & Univ. Tokyo & Aeta tribe, Bataan Peninsula, Luzon \\
\hline Filipino & 14 & Univ. Tokyo & $\begin{array}{l}\text { Near contemporary Filipinos, Marcos village, } \\
\text { Luzon }\end{array}$ \\
\hline
\end{tabular}


pelago and East as well as Southeast Asia. Table 1 shows the numbers of individuals studied, the locations where the materials are curated and the provenience of each sample. Fig. 1 shows the approximate source locations of the samples of Nansei Islanders. The present study includes more

East China sea

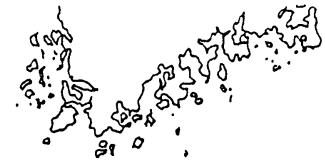

Korea

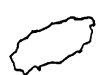

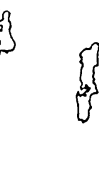
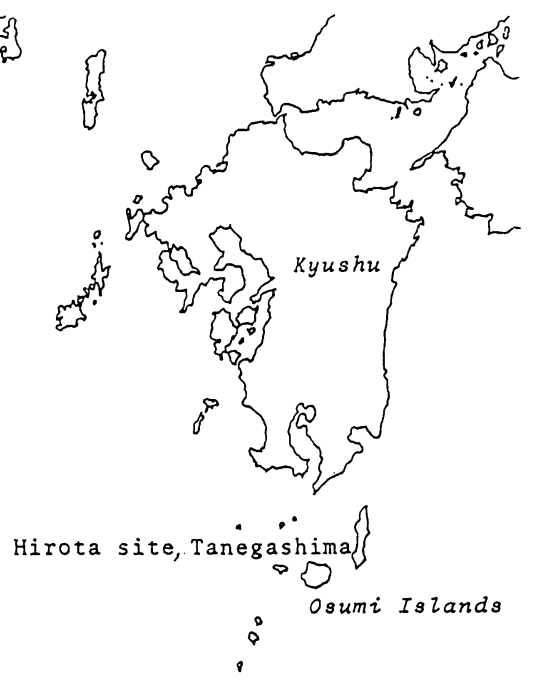

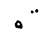

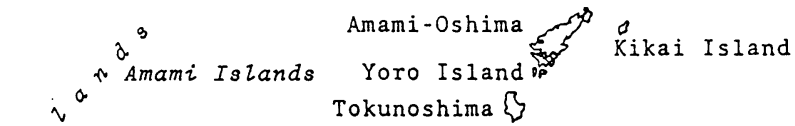

s.

Okinoerabu Island $\square$$$
1
$$

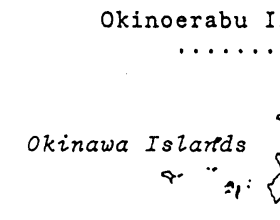

?

$a^{\circ}$

$n^{5}$

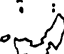

Okinawa

Pacific Ocean

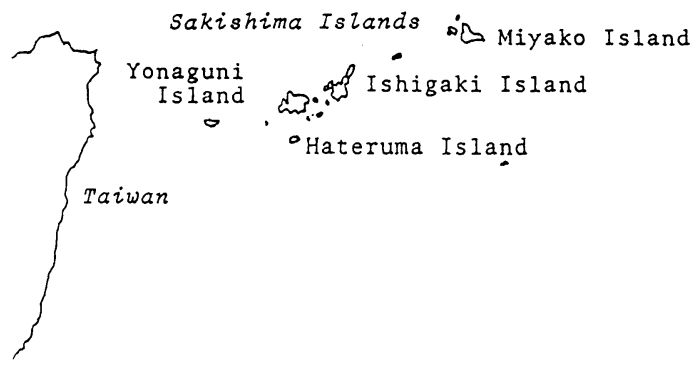

Fig. 1. Map showing approximate locations for the samples of the Nansei Island chain. 
than 300 individuals from the Nansei Island chain including prehistoric skeletal remains from Hirota site at Tanegashima Island. Using geography and culture as the primary sorting criteria, the individuals from the Nansei Island chain are divided into 4 groups, Hirota, Amami-, Okinawa-, and Sakishima-Islands. The comparative data consist of 7 samples from mainisland Japan, East and Southeast Asia. One Aeneolithic Yayoi sample excavated from Kanenokuma site, the northern part of Kyushu, Fukuoka Prefecture, is now believed to be the immigrant from Northeast Asia (e.g. HANIHARA, K., 1987, 1991: DODO and ISHIDA,
1990).

All the data were recorded by myself. The metric data were recorded on male specimens. The mesiodistal crown diameters were measured on all the teeth except for the maxillary and mandibular third molars. The non-metric observations were recorded on both male and female specimens since sexual dimorphism was insignificant in most of the samples observed. The sample size for non-metric observations varies depending on the specimen's state of preservation. The exact sample sizes of Nansei Islanders for each trait are given in Table 2. The traits recorded are: shovelling (upper 1st incisors);

Table 2. Frequency distributions of discrete crown traits in each sample from the Nansei Island chain (in $\%$; parenthesis, the numbers of teeth observed)

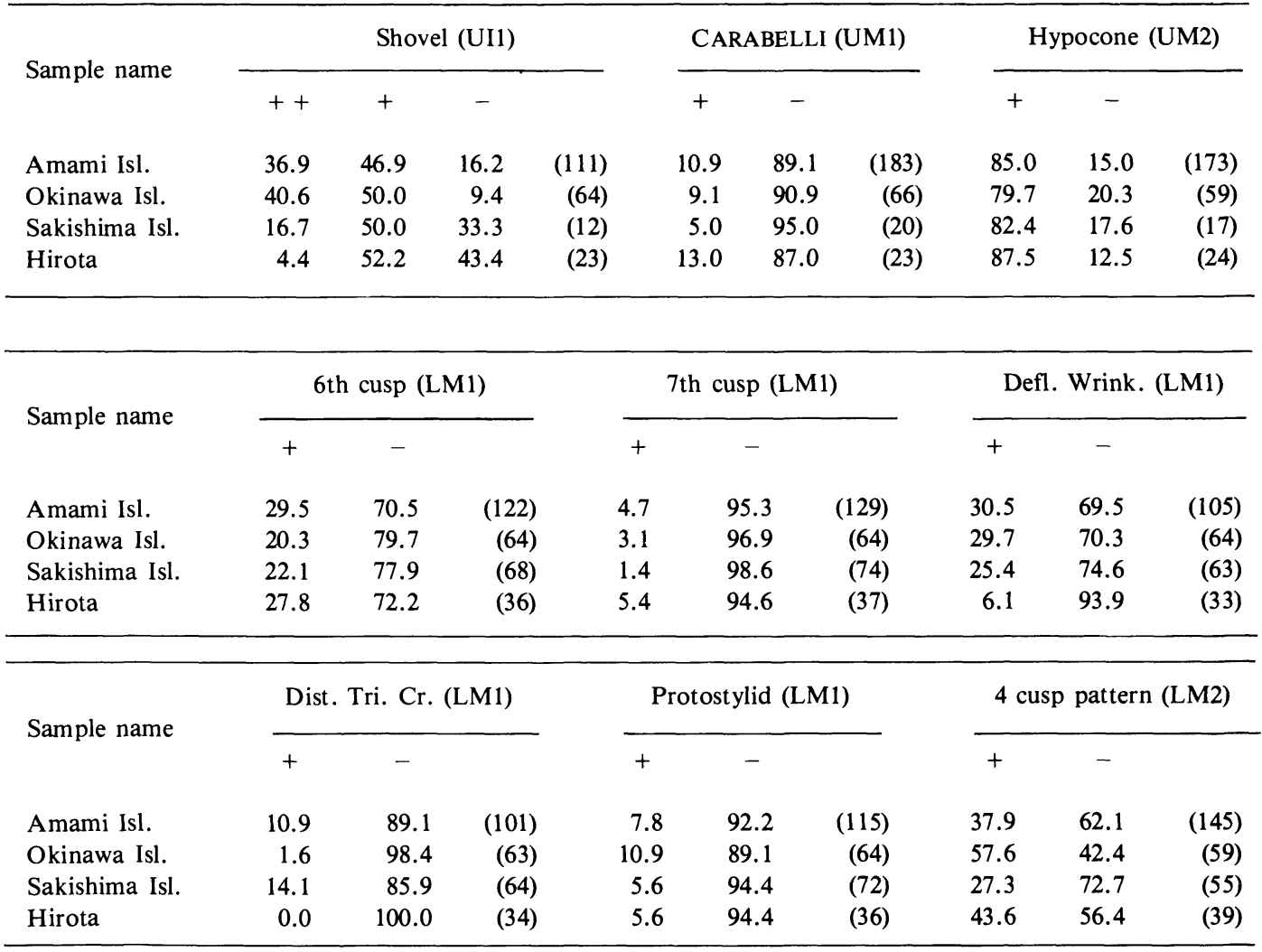


CARABELli's cusp (upper 1st molars); hypocone (upper 2nd molars); the 6th cusp, the 7th cusp, deflecting wrinkle, distal trigonid crest, and protostylid (lower 1st molars); and 4 cusp pattern (lower 2nd molars). The information of the criteria for classification of discrete characters was given elsewhere (HANIHARA, T. 1990b, 1991b, c, n.d. a, b). Metric and non-metric traits were scored per individual, not per side.

With the computer program coded by $\mathrm{K}$. HANIHARA, distance analysis based on Q-mode correlation coefficients between every pair of samples was applied to the dental measurements, and B-square distance analysis developed by BALAKRISHNAN and SANGHVI (1968) was applied to a data set based on the discrete crown traits. Dendrograms and two dimensional expressions were constructed from the distance matrices by applying cluster analysis and multidimensional scaling method, respectively.

\section{Results}

In the metric analysis, inter-group relationships of 3 prehistoric and 9 near-contemporary samples described in the previous chapter were analyzed. Fig. 2 is a dendrogram of relationship based on a cluster analysis, and Fig. 3 shows a two dimensional scattergram obtained by a multidimensional scaling method, accounting for $88.3 \%$ of the total variance. In these representations, 4 samples from the Nansei Island chain, 2 Southeast Asian samples, and Jomonese sample form a cluster. The samples of Honshu and Kyushu Japanese, Chinese, Koreans, and Kanenokuma comprise another cluster. In the first cluster, the sample from Sakishima Islands is closely related to those of Jomonese and Hirota. Two Southeast Asian samples, Negritos and Filipinos, occupy an intermediate position between Amami-Okinawa Island group and Sakishima-Hirota-Jomonese one in Fig. 3.

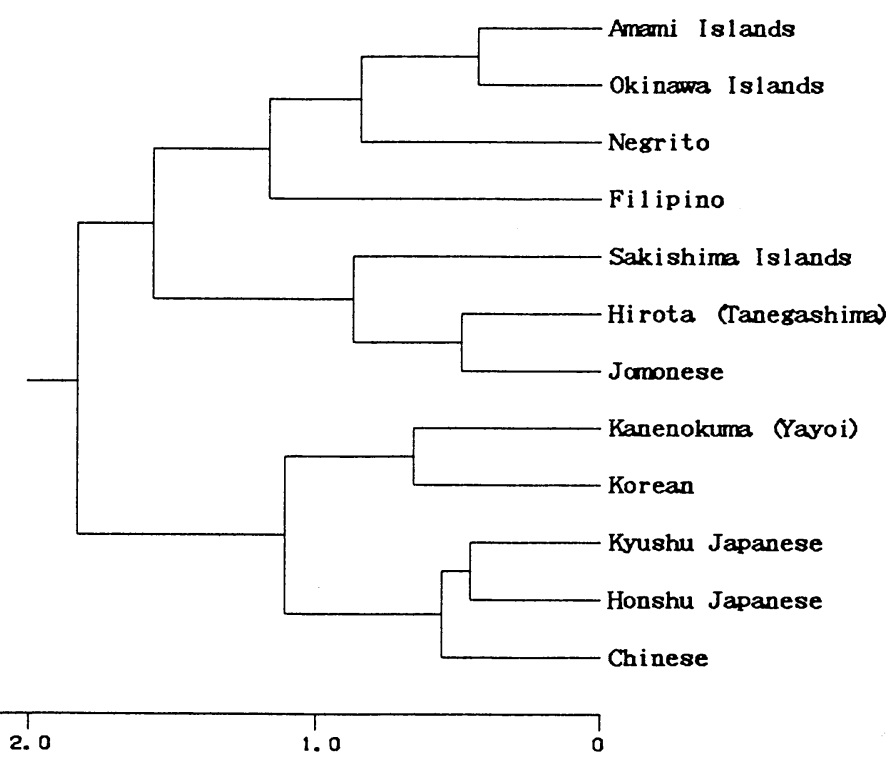

Fig. 2. Cluster analysis applied to Q-mode correlation coefficients based on $\mathrm{M}-\mathrm{D}$ crown diameters. 


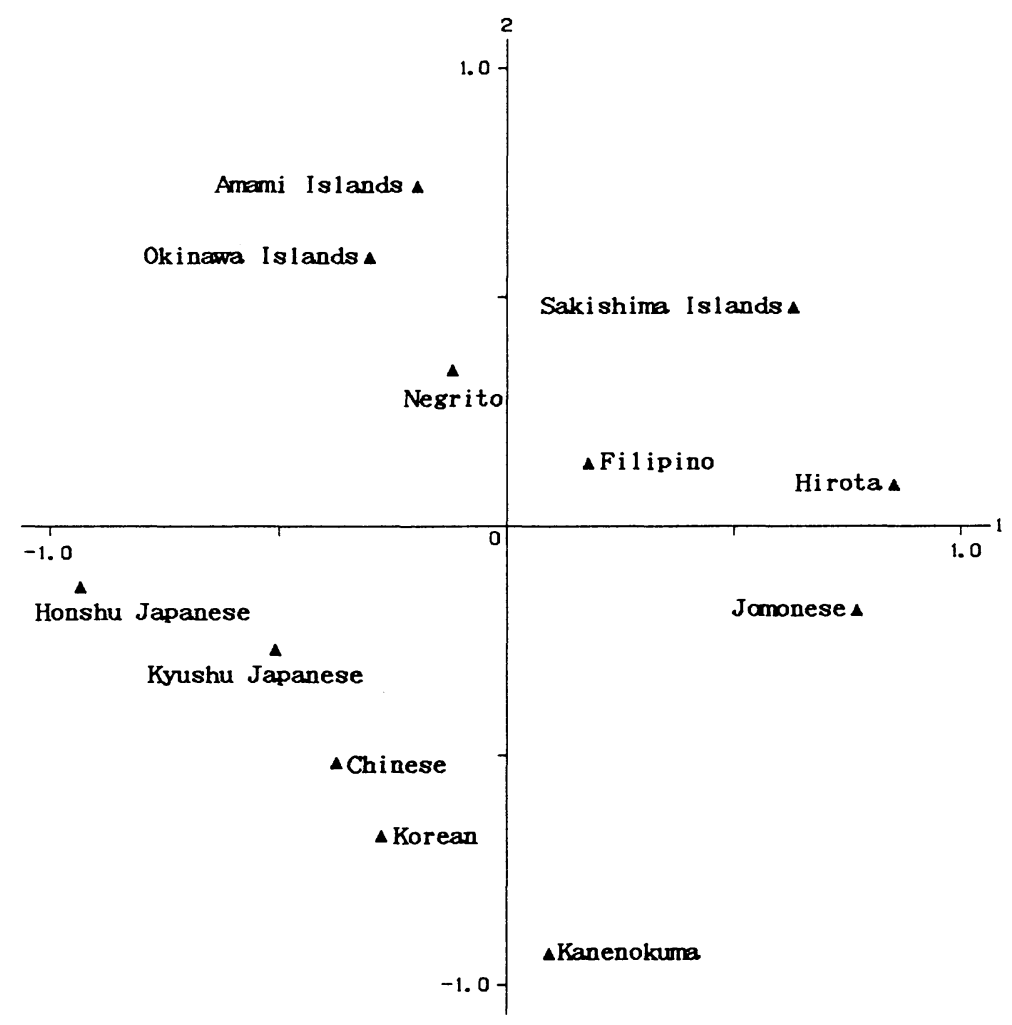

Fig. 3. Two-dimensional expression of multidimensional scaling applied to the same distance matrix used in Fig. 2, expressing $88.3 \%$ of total variance.

Fig. 4 shows the result of cluster analysis applied to the B-square distance coefficients based on 9 discrete crown traits for 11 samples. Two main clusters are evident. One contains samples of sinodont dental groups, namely, Honshu Japanese, Chinese, Koreans, and Kanenokuma. All the Nansei Island samples, Kyushu Japanese, and Negritos are included in another cluster, corresponding to the sundadont dental groups. With the exception of Kyushu Japanese, the two major clusters correspond to the association implied in Figs. 2 and 3. Fig. 5 shows a two dimensional expression drawn by a multidimensional scaling method on the basis of the same distance coefficients used in Fig. 4. In this figure, $84.1 \%$ of the total variance is expressed. The scattering pattern of each sample in this figure is to some extent in agreement with that in Fig. 3. In Fig. 5, two major constellations are also evident. The samples of Jomonese, Hirota, and Sakishima Islands form a single subbranch in the sundadont dental group. Amamiand Okinawa-Island samples form another subbranch.

The findings presented here is almost in full agreement with a 'dual structure model' for the population history of Japanese (HANIHARA, K., 1991). 


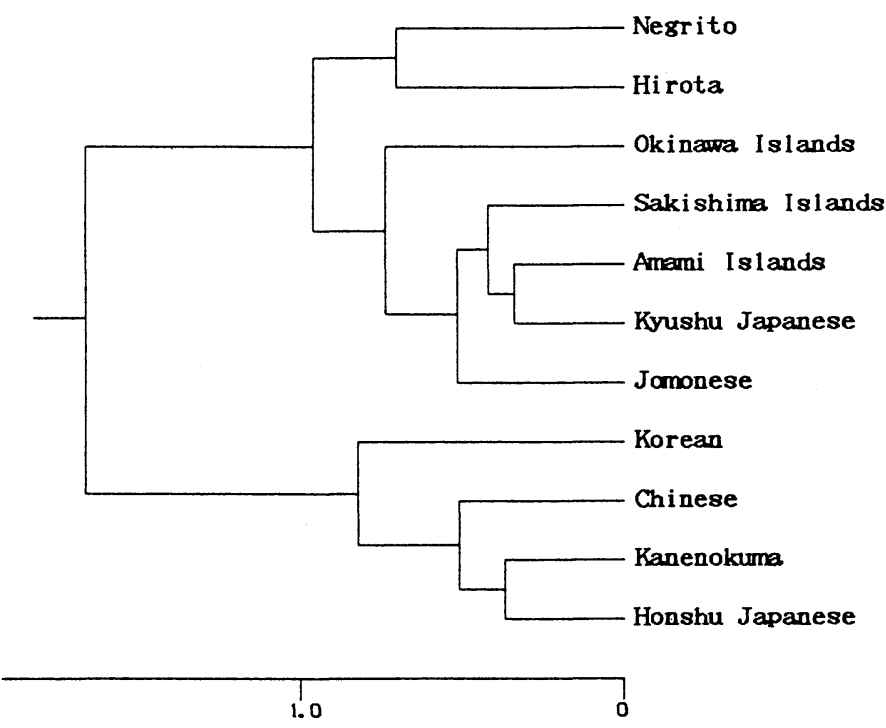

Fig. 4. Cluster analysis applied to B-square distance coefficients based on 9 discrete crown traits.

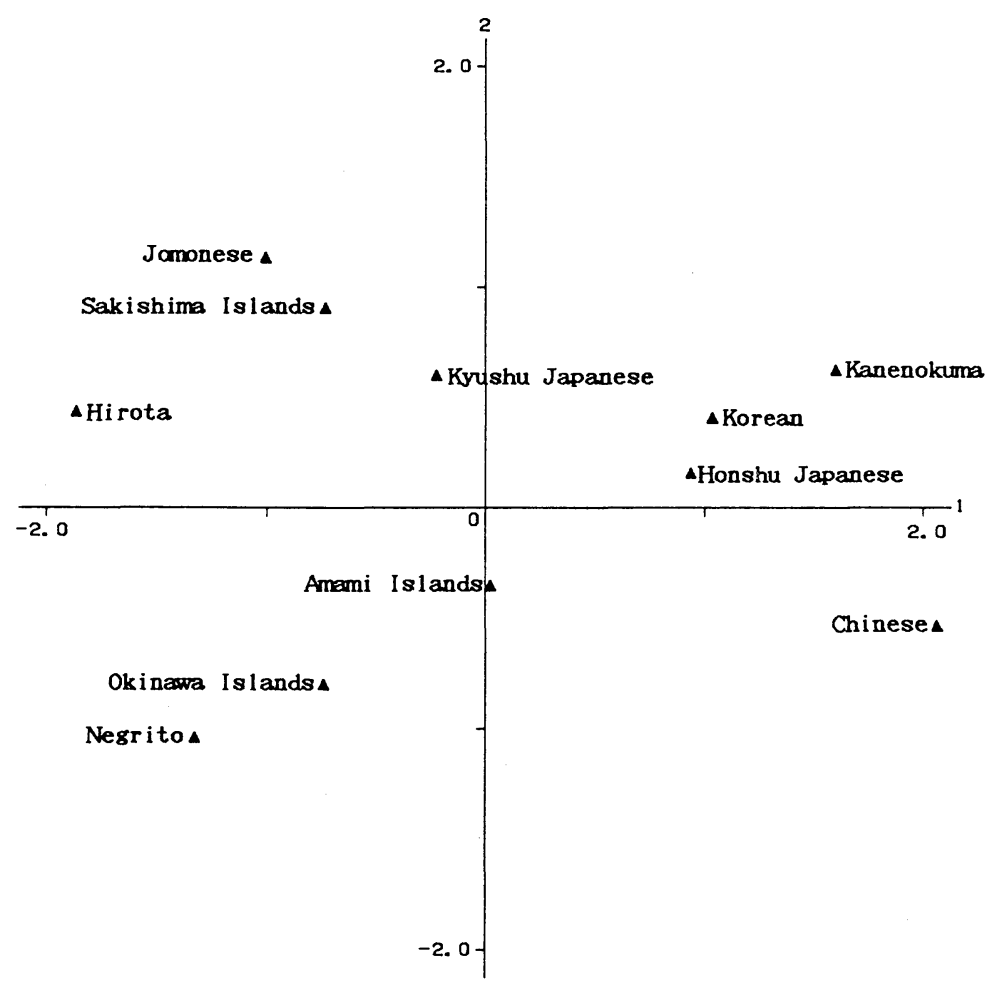

Fig. 5. Multidimensional scaling method applied to B-square distance values used in Fig. 4, in which $84.1 \%$ of total variance is expressed. 


\section{Discussion}

The approximate congruency of the metric and non-metric results obtained in the present study may be sufficient to allow some general statements concerning the possible origins and microevolution of Nansei Islanders.

The physical features and affinities of Nansei Islanders have so far been described (OYAMA, 1956; HIRATA, 1958; NAKANO, 1958; HIROZAWA, 1959; IWAI, 1959; KIKUCHI, 1959; OYADOMARI, 1968; SAKIHARA, 1968; TOMIZAWA, 1969; NAITO, 1973; TAGAYA and IKEDA, 1976). Recent investigations affirm that Nansei Islanders retain some physical features linked with those of Ainu and Jomonese (HANIHARA, K. et al., 1973; IKEDA, 1974; OMOTO, et al., 1973, 1975; HANIHARA, K., 1983, 1991; TURNER, 1987; HANIHARA, T., 1989a, b, c, 1990a, b, c, 1991a, b, c, n.d. a, b; KOZINTSEV, 1990). However, the geographical variation of the physical characteristics of Nansei Islanders are still incompletely documented.

The present findings provide an extensive base for viewing human variation within the region. All the Nansei Islanders' dental samples are similar to each other, Jomonese, and Southeast Asians than they are to Honshu Japanese, the immigrant Yayoi people (Kanenokuma), Chinese, and Koreans. The dental variation within the island chain shows a south-north gradient. Amami- and Okinawa-Islands show closer relationship to main-island Japanese than Sakishima Islands do. This regional variation may reflect the biocultural microevolution and the difference of the amount of admixture with sinodont mainisland Japanese through the time from the prehistoric to recent ages. The sample of Sakishima Islands and prehistoric JomoneseHirota group have sufficient metric and nonmetric dental similarity to suggest that the former may have retained some archaic dental characters even to the present day. Moreover, the dental characteristics of 2 Southeast Asian samples from the Philippines have something in common with those of 4 Nansei Island groups and Jomonese.

The archaeological records may substantiate this south-north physical division. The prehistoric Nansei Islands contain three distinct ceramic cultural groups (CHINEN, 1990). The prehistoric culture of Osumi Islands, including Tanegashima and Yakushima, is classified into the northern cultural group, one which is most closely related to that of South Kyushu. Amami- and OkinawaIslands are referred to as the central cultural group. This group shares the cultural ties with the northern group. On the other hand, the prehistoric culture of Sakishima Islands is linked with those of Taiwan and the Philippines, not with those of Okinawa, Amami, and Kyushu (CHINEN, 1990).

TURNER's dental hypothesis confirms that the sundadont ancestors of Jomonese could have arrived from Southeast Asia, or Sundaland, via the now-submerged East Asian continental shelf in the late Pleistocene and early Holocene times (TURNER and SWINDLER, 1978; TURNER, 1979, 1987, 1989, 1990). Taking the association of TURNER's hypothetical late Pleistocene Sundaland populations and the aboriginal Southeast Asians, or tentatively termed as 'generalized Asiatic populations' (HANIHARA, T. 1991a, c), in combination with the cultural and physical findings presented here into account, it is probable that one of the main routes for the northern extension of the ancestors of Jomonese, or the members of the late Pleistocene Sundaland populations, might have been through the Nansei Island chain. This route and origin hypothesis is supported by the craniofacial and dental affinities between Minatogawa man from Okinawa and Jomonese (SUZUKI and HANIHARA, K., 1982; TURNER, 1987, 1990; WU, 1990; HANIHARA, T. 
$1991 b, c)$.

\section{Acknowledgements}

I wish to express my sincere gratitude to Dr. T. NAKAHASHI, Dr. N. DoI, and Prof. Y. SHIBATA of Department of Anatomy, Faculty of Medicine, Kyushu University; Prof. $\mathrm{H}$. ISHIDA and Prof. K. KATAYAMA of Department of Zoology, Faculty of Science, Kyoto University; Prof. G. ITO of Department of Orthodontics, Kagoshima University Dental School; Prof. T. YOHRO of Department of Anatomy, Faculty of Medicine, Prof. K. OMOTO and Prof. B. ENDO of Department of Anthropology, Faculty of Science, Prof. T. AKAZAWA of Department of Anthropology and Prehistory, the University Museum, the University of Tokyo; for their kind permission to study the materials under their care.

I am grateful to Prof. K. HANIHARA of International Research Center for Japanese Studies for his critical advice and helpful remarks of the manuscript.

This study was supported in part by the following grants: Overseas Scientific Surveys, "The Population Genetic Survey of Negritos" organized by Prof. K. ОмоTO; Scientific Research of the Ministry of Education, Science and Culture in Japan; "Phylogenetic Analysis of Modern Japanese as Viewed from Dental Characters", No. 01740483; "Re-consideration of Origin and Affinities of Ainu Based on Dental Characters", No. 02740412; “Origin of Japanese as Viewed from Dental and Craniofacial Morphology", No. 03740424; and "The Basic Populations in East Asia as Viewed from Dental Characters", Nos. 02225213 \& 03209210.

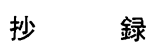

南西諸島民の歯冠形態と縄文人の日本列島への拡散

埴原恒彦
縄文人が後期更新世から完新世初期にかけて日本列 島に拡散していったことはほぼ間違いないであろう。 彼らの人種的, 地理的起源に関しても，筆者は，後 期更新世にスンダランドで進化してきた集団が，今 は水没してしまった東アジアの大陸棚づたいに北上 してきたとする，C．Ｇ．ターナーの仮説を支持する 分析結果を示してきた．それでは，日本列島への拡 散ルートについては, どのように考えられるのか. 港川人の発見によって, 南西諸島がこのルートの一 つと考えることが可能になったと思われるが，他の 形質人類学的追証は殆どなされていない，本研究で は, この問題へのアプローチの一つとして, 先史時 代を含む南西諸島のほぼ全域から歯冠形質に関する データを収集し, 縄文人, 東アジア及び東南アジア 諸集団との比較分析を試みた。

分析は, 南西諸島集団を 4 つの地理的グループ （広田遺跡集団一種子島, 奄美諸島, 沖縄諸島, 先島 諸島）に分けておこなった。 その結果, 南西諸島諸 集団, とくに, 最南端に位置する先島諸島集団は, 今日であ縄文人の形質をかなり濃厚に受け継いでい ることが明かとなった。 それと同時に，これらの諸 集団の歯冠形質には, 地理的勾配が認められた。こ れらの結果から, 近世の南西諸島民の歯冠形質は, 縄文人のそれを基盤とし，過去数千年間にわたり， 環境及び文化的影響, また, 本土の集団からの遺伝 的寄与を受けながら，小進化してきたものと考えら れる. 全体としては, 南西諸島民の歯冠形質は, 本 州日本人, 朝鮮人, 中国人ょりも東南アジア集団 （フィリピン人，ネグリト）に類似する.

以上のことから，スンダランドから拡散していっ た集団は, 南西諸島をその北上ルートの一つとして, 日本列島に拡散していった可能性があるものと思わ れる。

\section{References}

BALAKRISHNAN, V. and L.D. SANGHVI, 1968: Distance between populations on the basis of attribute data. Biometrics, 24: 859-865.

CHINEN, I., 1990: Cultural perspective of Nansei Islands. New Theories for Culture in Japan, Gakken, Tokyo, pp. 129-131. (In Japanese)

[知念勇, 1990 : 輻輳する南西諸島の文化一九州起 源だけでは解けない文化様相. 最新日本文化起源 論, 学研, 東京, pp. 128-131]

DODO, Y. and H. ISHIDA, 1990: Population history of Japan as viewed from cranial nonmetric variation. 
J. Anthrop. Soc. Nippon, 98: 269-287.

HANIHARA, K., T. MASUDA and T. TANAKA, 1973: Affinities of dental characteristics in the Okinawa Islanders. J. Anthrop. Soc. Nippon, 82: 75-82.

HANIHARA, K., 1983: Ainu and Ryukyus (Okinawa Islanders). Recent Progress of Natural Sciences in Japan. Vol. 8. Science Council of Japan, Tokyo, pp. 25-30.

HANIHARA, K., 1985: Geographic variation of modern Japanese crania and its relationship to the origin of Japanese. Homo, 36: 1-10.

HANIHARA, K., 1987: Estimation of the number of early migrants to Japan: A simulative study. J. Anthrop. Soc. Nippon, 95: 391-403.

HANIHARA, K., 1991: Dual structure model for the population history of Japanese. Japan Review, 2: 1-33.

HANIHARA, T., 1989a: Comparative studies of dental characteristics in the Aogashima islanders. J. Anthrop. Soc. Nippon, 97: 9-22.

HANIHARA, T., 1989b: Comparative studies of geographically isolated populations in Japan based on dental measurements. J. Anthrop. Soc. Nippon, 97: 95-107.

HANIHARA, T., 1989c: Affinities of the Philippine Negritos as viewed from dental characters: A preliminary report. J. Anthrop. Soc. Nippon, 97: 327-339.

HANIHARA, T., 1990a: Affinities of the Philippine Negritos with modern Japanese and the Pacific populations based on dental measurements: The basic populations in East Asia. I. J. Anthrop. Soc. Nippon, 98: 13-27.

HANIHARA, T., 1990b: Dental anthropological evidence of affinities among the Oceania and the Pan-Pacific populations: The basic populations in East Asia, II. J. Anthrop. Soc. Nippon, 98: 233-246.

HANIHARA, T., 1990c: Studies on the affinities of Sakhalin Ainu based on dental characters: The basic populations in East Asia, III. J. Anthrop. Soc. Nippon, 98: 425-437.

HANIHARA, T., 1991a: Origin and microevolution of Ainu as viewed from dentition: The basic populations in East Asia, VIII. J. Anthrop. Soc. Nippon, 99: 345-361.

HANIHARA, T., 1991b: Dental and cranial evidence on affinities of the East Asian and Pacific populations. In: HANIHARA, K. (ed.): Japan in the World: Japanese as a Member of the Asian and Pacific Populations. International Research Symposium No. 4, IRCJS Press, Kyoto, pp. 119-137.

HANIHARA, T., 1991c: Population Prehistory of East Asia and the Pacific in the Late Pleistocene and Holocene: A Dental and Craniofacial Perspective.
HANIHARA, T., (n.d.a) Negritos, Australian Aborigines and the "proto-sundadont" dental pattern: The basic Doctoral Dissertation, The University of Tokyo.

HANIHARA, T., (n.d.a): Dental and cranial affinities among the populations in East Asia and the Pacific: The basic populations in East Asia, IV. Am. J. Phys. Anthropol. (in press)

HANIHARA, T., (n.d.b) Negritos, Australian Aborigines and the "proto-sundadont" dental pattern: The basic populations in East Asia, V. Am. J. Phys. Anthropol. (in press)

HIRATA, K., 1958: Studies on the lower extremity bones of Yoron Islanders, Oshima-gun, Kagoshima Prefecture, Japan. Quart. J. Anthropol., 5: 263-315. (In Japanese with English summary)

HiRoZAWA, M., 1959: Anthropological studies on the upper extremity bones in the inhabitants of Yoron Island in the Amami Archipelago, Japan. Quart. J. Anthropol., 6: 71-108. (In Japanese with English summary)

IKEDA, J., 1974: Craniometry of Miyako Islanders, the Ryukyus. J. Anthrop. Soc. Nippon, 82: 150-160. (In Japanese with English summary)

IWAI, S., 1959: Studies on crania of the natives of Tokunoshima, Oshima-gun, Kagoshima Prefecture. Med. J. Kagoshima Univ., 11: 295-335. (In Japanese with English summary)

KIKUCHI, J., 1959: An anthropological study of the cranial bones of the Yoro islanders, Oshima-gun, Kagoshima Prefecture, Japan. Quart. J. Anthropol., 6: 366-398. (In Japanese with English summary)

KozINTSEV, A., 1990: Ainu, Japanese, their ancestors and neighbours: Cranioscopic data. J. Anthrop. Soc. Nippon, 98: 247-267.

NAITO, Y., 1973: Anthropological studies of the Nansei islanders. Jinruikagaku, 25: 163-194. (In Japanese)

[内藤芳篤, 1973 : 南西諸島住民の人類学的研究. 人類科学, $25: 163-194]$

NAKANO, T., 1958: An anthropological study on the skulls of Kikai islanders of Amami Archipelago, Japan. Quart. J. Anthropol., 5: 188-219. (In Japanese with English summary)

OMOTO, K., K. ISHIZAKI, S. HARADA, S. AKAISHI, T. KUDO and K. TAKAHASHI, 1973: The distribution of serum protein and red cell enzyme types among blood donors of Okinawa island, the Ryukyus. J. Anthrop. Soc. Nippon, 81: 159-173.

Омото, K., G. ISHIMOTO, S. HARADA and S. MISAWA, 1975: The distribution of genetic markers in blood samples from Okinawa, the Ryukyus. II. The distribution of several red cell enzyme types in Ishigaki island. J. Anthrop. Soc. Nippon, 83: 253-260.

OYADOMARI, G., 1968: Physical and anthropological 
studies on the inhabitants of the northern district in Okinawa island, Ryukyu. Nagasaki Igakukai Zasshi, 43: 632-653. (In Japanese with English summary)

OYAMA, H., 1956: Craniological studies on the Yoron islanders, Oshima-gun, Kagoshima Prefecture, Japan. Quart. J. Anthropol., 3: 92-130. (In Japanese with English summary)

SAKIHARA, E., 1968: Physical and anthropological studies on the inhabitants of the middle district in Okinawa island, Ryukyu. Nagasaki Igakukai Zasshi, 43: 654-678. (In Japanese with English summary)

SUZUKI, H. and K. HANIHARA (eds.), 1982: The Minatogawa man. The upper Pleistocene man from the island of Okinawa. Bulletin of the University Museum, the University of Tokyo, No. 19.

TAGAYA, A. and J. IKEDA, 1976: A multivariate analysis of the cranial measurements of the Ryukyu islanders (males). J. Anthrop. Soc. Nippon, 84: 204-220.

TOMIZAWA, T., 1969: Physical and anthropological studies on the inhabitants of Tokunoshima island in Amami Archipelago, Japan. Nagasaki Igakukai Zasshi, 44: 45-69. (In Japanese with English summary) TURNER, C.G. II, 1976: Dental evidence on the origin of the Ainu and Japanese. Science, 193: 911-913.

TURNER, C.G. II, 1979: Dental anthropological indications of agriculture among the Jomon of central Japan. Am. J. Phys. Anthropol., 51: 619-636.

TURNER, C.G. II, 1987: Late Pleistocene and Holocene population history of East Asia based on dental variation. Am. J. Phys. Anthropol., 73: 305-321.

TURNER, C.G. II, 1989: Teeth and prehistory in Asia. Scientific American, February: 70-77.

TURNER, C.G. II, 1990: Major features of sundadonty and sinodonty, including suggestions about East Asian microevolution, population history and late Pleistocene relationships with Australian Aboriginals. Am. J. Phys. Anthropol., 82: 295-317.

TURNER, C.G. II and D.R. SWINDLER, 1978: The dentition of New Britain west Nakanai Melanesians. VIII. Peopling of the Pacific. Am. J. Phys. Anthropol., 49: 361-372.

WU, X., 1990: Origins and affinities of the inhabitants of Japan in different period. Paper presented to International Symposium on Japanese as a Member of the Asian and Pacific Populations. Int. Res. Center for Japanese Studies, Kyoto, 1990.
埴 原 恒 彦

Tsunehiko HANIHARA Department of Anatomy, Jichi Medical School

Minamikawachi-Cho, Kawachi-Gun, Tochigi, 239-04, Japan

自治医科大学解剖学教室

₹329-04 栃木県河内郡南河内町 